\title{
Morpho-physiological and Biochemical Characterization of Rice (Oryza sativa L.) Genotypes under Ammonical and Nitrate form of Nitrogen
}

\author{
Mayur R. Wallalwar*, Rashmi Upadhyay, Jyoti Singh, Datta P. Kakade, \\ Shubha Banerjee and Satish B. Verulkar
}

\author{
Department of Plant Molecular Biology and Biotechnology, College of Agriculture, \\ Indira Gandhi Krishi Vishwavidyalaya, Raipur, Chhattisgarh, India, Pin-492012 \\ *Corresponding author
}

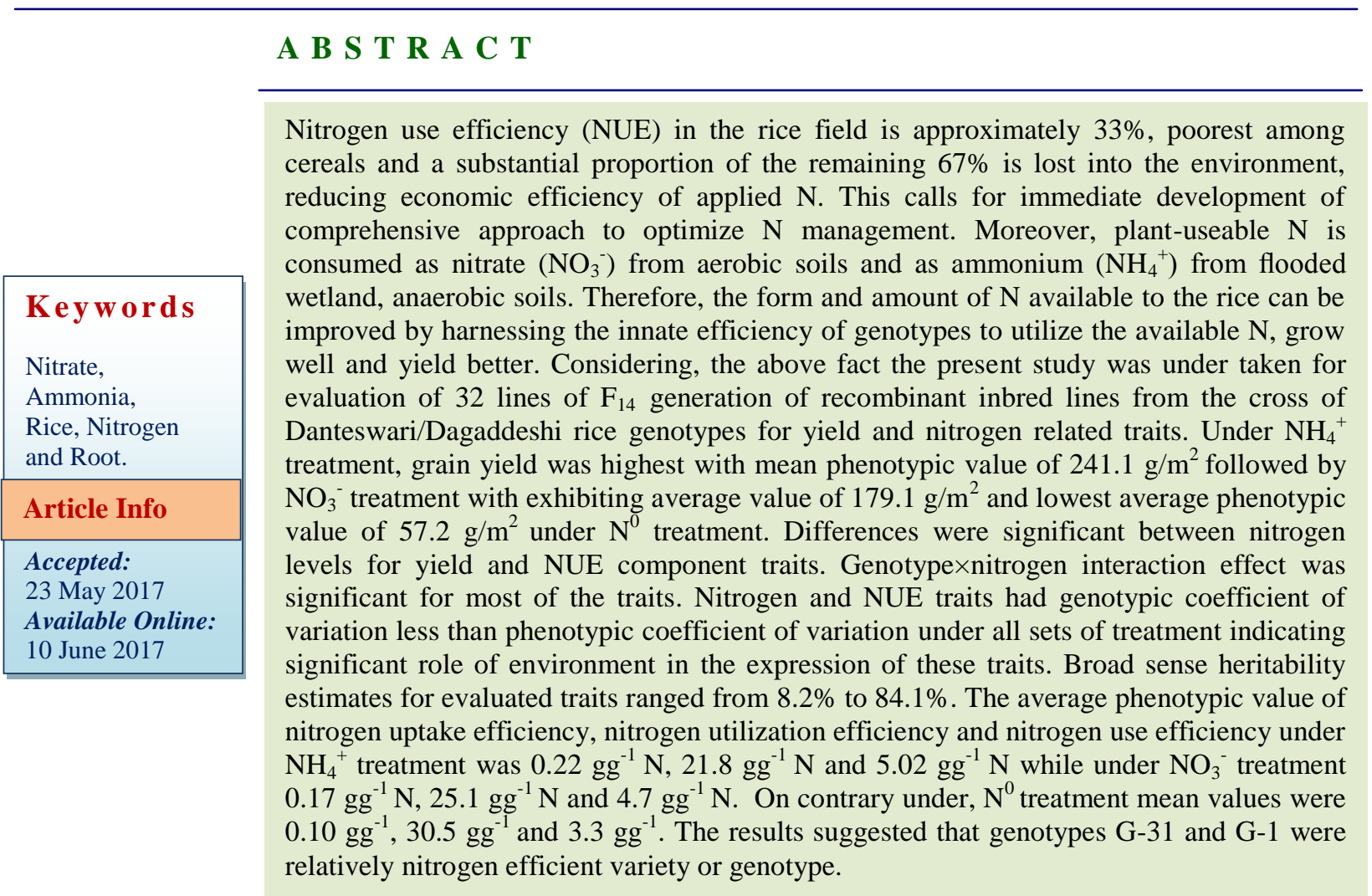

\section{Introduction}

Nitrogen $(\mathrm{N})$ is one of the most critical inputs that define crop productivity and yield under field conditions and must be supplemented to meet the food production demands of an everincreasing. Furthermore, the statistics reveals that the doubling of agricultural food production worldwide over the past 4 decades has been associated with a 7-fold increase in the use of nitrogen fertilizers. The current average nitrogen use efficiency (NUE) in the rice field is approximately $33 \%$, poorest among cereals and a substantial proportion of 
the remaining $67 \%$ is lost into the environment $\mathrm{N}$ reducing economic efficiency of applied N. This calls for immediate development of comprehensive approach to optimize $\mathrm{N}$ management in every sphere of life. Moreover, plant-useable $\mathrm{N}$ is consumed as nitrate $\left(\mathrm{NO}_{3}{ }^{-}\right)$from aerobic soils and as ammonium $\left(\mathrm{NH}_{4}^{+}\right)$from flooded wetland, anaerobic soils. Therefore, the form and amount of $\mathrm{N}$ available to the rice can be improved by harnessing the innate efficiency of genotypes/species to utilize the available $\mathrm{N}$ and grow well and yield better.

Nitrogen use efficiency (NUE) in plants is a complex quantitative trait that involves many genes and depends on a number of internal and external factors in addition to soil nitrogen availability (Gupta et al., 2010). NUE at the plant level includes nitrogen uptake and assimilatory processes, redistribution within the cell and balance between storage and current use at the cellular and whole plant level, rice genotypes shows significant variability for $\mathrm{N}$ uptake (external efficiency) and $\mathrm{N}$ utilization (internal efficiency) with yield being predominantly determined by the uptake process, particularly under low-N conditions (Witcombe et al., 2008). Predominant forms of $\mathrm{N}$ changes with change in water availability. Plant-useable $\mathrm{N}$ is consumed as nitrate $\left(\mathrm{NO}_{3}{ }^{-}\right)$from aerobic soils and as ammonium $\left(\mathrm{NH}_{4}{ }^{+}\right)$from flooded wetland, anaerobic soils (Huang et al., 2000). Field drainage has profound effect on $\mathrm{N}$ dynamics in soil. When the field is drained and the soil becomes aerobic, ammonium is oxidized through microbial processes (known as nitrification) into nitrate $\left(\mathrm{NO}_{3}{ }^{-}\right)$. Rice roots are exposed to a mixed $\mathrm{N}$ forms in rhizosphere (Briones et al., 2003; Li et al., 2003) but it prefers to utilize ammonium $\left(\mathrm{NH}_{4}{ }^{+}\right)$over nitrate $\left(\mathrm{NO}_{3}{ }^{-}\right)$as rice is pertained to waterlogged growth conditions (Li et al., 2009). Rice root and whole metabolic system has evolved and adopted for efficient utilization of $\mathrm{NH}_{4}{ }^{+}$as compared to $\mathrm{NO}_{3}{ }^{-}$. It is therefore not surprising that $\mathrm{NH}_{4}{ }^{+}$nutrition, as opposed to $\mathrm{NO}_{3}{ }^{-}$nutrition, has received almost exclusive attention in rice (Wang et al., 1993). However, kinetic and comparative analysis of ammonium and nitrate acquisition by Kirk and Kronzucker (2000) has opened new insight for $\mathrm{NO}_{3}{ }^{-}$nutrition studies.

Present study was under taken for evaluation of 32 lines of $\mathrm{F}_{14}$ generation of recombinant inbred lines (RILs) from the cross of Danteswari/Dagaddeshi rice genotypes for yield and nitrogen related traits and the relationship between root and nitrogen use efficiency (NUE) traits was further elucidated. It also helps to elucidate the Genotype $\times$ nitrogen interaction effect in rice.

\section{Materials and Methods}

\section{Plant material and experimental site}

Field experiment was conducted in research cum instructional farm of College of Agriculture, IGKV, Raipur. 25 lines of recombinant inbred lines (RILs) developed from the cross of Danteshwari /Dagaddeshi along with 7 parents were chosen as experimental materials and evaluated under irrigated condition. The whole experiment was accomplished during growing season 2015.

\section{Fertilizer treatments}

The experiment was laid out as factorial in randomized complete block design (RCBD) with two replications. Treatments involved in the experiment consisted of three nitrogen fertilizers levels.

$\mathrm{L}_{1}=$ Ammonium sulphate providing ammonical nitrogen $\left(\mathrm{NH}_{4}{ }^{+}-\mathrm{N}\right)$

$\mathrm{L}_{2}=$ Calcium nitrate providing nitrate nitrogen $\left(\mathrm{NO}_{3}{ }^{-} \mathrm{N}\right)$

$\mathrm{L}_{3}=$ Control having no nitrogen fertilizer $\left(\mathrm{N}^{0}-\right.$ $\mathrm{N}$ ) 
Physcio-chemical characteristics of soil of the experimental field

The experimental soil (Vertisol) is fine montmorillonite, hyperthermic, udic chromustert, locally called as Kanhar and is identified as Arang II series. It is usually deep, heavy, clayey, dark brown to black in colour and neutral. Soil from experimental fields was analyzed for its initial characteristics and some important physiochemical properties of the soil are given in table 1 .

\section{Nursery and transplanting}

Well pulverized raised nursery beds were prepared. The size of each nursery beds were $1 \times 25 \mathrm{~cm}$ drainage channel of $30 \mathrm{~cm}$ width was provided between the beds. Twenty three days old seedlings and single seedling per hill was transplanted in the field. The fertilizers were applied as per the recommended package of practice. The ratio of $80: 60: 40 \mathrm{~kg}$ $\mathrm{ha}^{-1} \mathrm{~N}$ : P: K was employed in the form of ammonium sulphate/ calcium nitrate, single super phosphate and murate of potash, respectively. Nitrogen was applied in 3 splits, viz. $50 \%$ of the total $\mathrm{N}$ as basal dose, $25 \%$ at panicle initiation and the remaining $25 \%$ at flowering. The whole amount of phosphorus and potash was applied as basal during transplanting.

\section{Observations recorded}

\section{Field studies}

Observation related to $\mathrm{N}$ use efficiency and yields were recorded according at particular stage and time. Various yield related observation viz., Seedling height $(\mathrm{cm})$, Total number of tillers (tillers $/ \mathrm{m}^{2}$ ), Days to $50 \%$ flowering, Plant height $(\mathrm{cm})$, Panicle length $(\mathrm{cm})$, Flag leaf length $(\mathrm{cm})$, Flag leaf width (cm), Flag leaf length: width ratio, Flag leaf area, Penultimate leaf length $(\mathrm{cm})$,
Penultimate width $(\mathrm{cm})$, Penultimate leaf length: width ratio, Biological yield $\left(\mathrm{g} / \mathrm{m}^{2}\right)$, Grain yield $\left(\mathrm{g} / \mathrm{m}^{2}\right)$, Grain yield per plant $\left(\mathrm{g} / \mathrm{m}^{2}\right)$, Straw yield $\left(\mathrm{g} / \mathrm{m}^{2}\right)$, Harvest index $(\%)$, Number of filled spikelet's per panicle, Number of unfilled spikelet's per panicle, Total number of spikelet's per panicle, Spikelet fertility (\%), Spikelet sterility (\%), Seed length (mm), Seed breadth (mm), Seed L: B ratio, Test weight (100 seeds weight) (g) were taken at specific stage.

\section{Physiological and biochemical parameter}

The observation of physiological trait under study was recorded between 11:00 AM to 14:30 PM in the bright sunny day, since the atmospheric condition during this period was relatively stable.

\section{Chlorophyll content}

Leaf chlorophyll content was measured by in vivo procedure using Soil Plant Analysis Diagnostic Meter (SPAD-502, 1989 Minolta Co. Ltd.)

\section{In vivo assay}

SPAD-502 was used to measure chlorophyll content of leaves in SPAD units. Leaf chlorophyll content was measured by light absorbance in the range of red and infrared with the chlorophyll meter in the middle region of fully open flag leaf and penultimate leaf of five representative plants. Readings were measured during seedling and flowering stages. Mean SPAD reading was recorded. SPAD reading is equivalent to chlorophyll content in $\mathrm{g} / \mathrm{cm}^{2}$.

Determination of nitrogen uptake and nitrogen efficiencies

Nitrogen uptake in seed and straw yields were computed by multiplying their respective nutrient contents with yields using of 
following formula:

Nutrient uptake $\left(\mathrm{kg} \mathrm{ha}^{-1}\right)$ in seed and straw $=$ Seed and straw yield $\times$ Nitrogen content

\section{Nitrogen use efficiency}

It was calculated by using the following formula

$$
\operatorname{NUE}(\%)=\frac{\text { Uptake from treated plot- Uptake from control plot }}{\text { Total fertilizer applied }} \times 100
$$

\section{Agronomic efficiency of nitrogen}

It was calculated by using the following formula

AEN $(\mathrm{kg} \mathrm{hac}-1)=\frac{\text { GYF }- \text { GYC }}{\text { AFN }}$

\section{Production efficiency}

It was calculated by using the following formula

PEN $(\mathrm{kg}$ grain $/ \mathrm{kg} \mathrm{N}$ absorbed $)=\frac{\text { GYF }- \text { GYC }}{\text { TUN }- \text { CUN }}$

Where,

$\mathrm{TU}_{\mathrm{N}}=$ Total $\mathrm{N}$ uptake from fertilized plot $(\mathrm{kg}$ $\mathrm{ha}^{-1}$ ),

$\mathrm{CU}_{\mathrm{N}}=$ Total $\mathrm{N}$ uptake from unfertilized control plot $\left(\mathrm{kg} \mathrm{ha}^{-1}\right)$,

$\mathrm{AF}_{\mathrm{N}}=$ The amount of applied fertilizer $\mathrm{N}(\mathrm{kg}$ $\mathrm{ha}^{-1}$ )

$\mathrm{GY}_{\mathrm{F}}=$ The grain yield in fertilized plot $(\mathrm{kg}$ ha $\left.{ }^{1}\right)$,

$\mathrm{GY}_{\mathrm{C}}=$ The grain yield in unfertilized control plot $\left(\mathrm{kg} \mathrm{ha}^{-1}\right)$,

$\mathrm{AE}_{\mathrm{N}}=$ Agronomic efficiency of $\mathrm{N}\left(\mathrm{kg} \mathrm{ha}^{-1}\right)$,

$\mathrm{PE}_{\mathrm{N}}=$ Production efficiency of $\mathrm{N}(\mathrm{kg}$ grain $/ \mathrm{kg}$ $\mathrm{N}$ absorbed).

\section{Statistical methods}

All data was analyzed by analysis of variance, and F-test was used to determine treatment significance. Duncan's multiple range test (DMRT) was used to compare treatment means at 5\% probability level using $\mathrm{M}$ STAT-C 14.2 software. Appropriate regression equations were also used for further analysis of relations between different parameters.

\section{Result and Discussion}

\section{Yield and yield related traits}

\section{Analysis of variance}

The RIL population along with parents was evaluated during wet season 2015 for various phonological, agronomical and physiological traits. The data recorded for various traits under varied $\mathrm{N}$ forms and water regimes was subjected to 3-way analysis of variance and the mean sum of square due to various source of variation/variance components for the investigated traits are presented in table 3. Analysis of variance revealed significant differences among the genotypes for most of the traits considered $(\mathrm{p}<0.05$ and $\mathrm{p}<0.01)$ indicating the presence of genetic variation among genotypes and possibility of manipulating these variations for improvement purposes. This is in accordance with the previous reports on rice by Fageria and Filho (2001). The genotype by nitrogen $(\mathrm{G} \times \mathrm{N})$ interaction component and genotype by environment interaction (GXE), which was of main consideration in present research was significant for most of the traits implying the performance of genotypes are significantly influenced by $\mathrm{N}$ forms and water regimes. This is persistent with the work of Hafele et al., (2008) who screened 19 rice genotypes adapted to different rice environments under two water and two nutrient treatments during the wet season of 2004 and 2005. They studied the variance components for grain yield and NUE traits and observed the significant effects for all main factors water $(\mathrm{W})$, nitrogen $(\mathrm{N})$ and genotype $(\mathrm{G})$ in both seasons. 


\section{Mean performance of genotypes}

The mean phenotypic performance of RILs and their parents for 19 characters recorded in kharif 2015 across differential $\mathrm{N}$ regimes and two environments is presented in tables 3 and 4. The mean values of two parents showed significant difference for almost 16 , out of all evaluated traits. The phenotypic values for these traits exhibited broad and continuous variation among the 122 RILs and significant transgressive segregation for both the parents, which might be attributed to the different background of the two parents and the polygenic inheritance of the trait. The coefficient of variation (CV) ranged from 6 to $48 \%$ for most of the traits under all sets of conditions, with the only two traits seed length (averaged $3 \%$ ) and spikelet sterility (66\%) showing extreme values.

Higher values were observed for all the studied traits at the $\mathrm{NH}_{4}{ }^{+}$treatment followed by $\mathrm{NO}_{3}^{-}$and $\mathrm{N}^{0}$ treatment across both environments. Among all the traits, grain yield, biological yield, harvest index, total tillers $/ \mathrm{m}^{2}$, plant height, days to $50 \%$ flowering that showed significant variation across varied sets of conditions are elaborated here. During wet season 2015, under irrigated condition average phenotypic value recorded in $\mathrm{NH}_{4}{ }^{+}$treatment for grain yield $\left(\mathrm{g} / \mathrm{m}^{2}\right)$, biological yield $\left(\mathrm{g} / \mathrm{m}^{2}\right)$, harvest index $(\%)$, Days to $50 \%$ flowering (days), plant height (cm), effective tiller/plant, total tiller/ plant was $284,849,34,76.4,106,6.9$ and 8.1 respectively. Mean phenotypic performance values estimated in $\mathrm{NO}_{3}{ }^{-}$treatment for grain yield $\left(\mathrm{g} / \mathrm{m}^{2}\right)$, biological yield $\left(\mathrm{g} / \mathrm{m}^{2}\right)$, harvest index (\%), Days to $50 \%$ flowering (days), plant height $(\mathrm{cm})$, effective tiller/plant, total tiller/ plant 233, 674, 35.2, 78.4, 97.7, 6.2 and 6.7 respectively. Mean phenotypic performance values recorded in $\mathrm{N}^{0}$ treatment for grain yield $\left(\mathrm{g} / \mathrm{m}^{2}\right)$, biological yield $\left(\mathrm{g} / \mathrm{m}^{2}\right)$, harvest index (\%), Days to $50 \%$ flowering (days), plant height $(\mathrm{cm})$, effective tiller/plant, total tiller/ plant was 221, 613, 35, 78.4, 96.1, 6.2 and 6.5 respectively. Within rainfed condition mean phenotypic values for grain yield $\left(\mathrm{g} / \mathrm{m}^{2}\right)$, biological yield $\left(\mathrm{g} / \mathrm{m}^{2}\right)$, harvest index (\%), Days to $50 \%$ flowering (days), plant height $(\mathrm{cm})$, total tiller/ $\mathrm{m}^{-2}$ under $\mathrm{NH}_{4}{ }^{+}$ treatment was 136, 588, 23, 76, 99 and 400 respectively. Mean phenotypic performance for grain yield $\left(\mathrm{g} / \mathrm{m}^{2}\right)$, biological yield $\left(\mathrm{g} / \mathrm{m}^{2}\right)$, harvest index (\%), Days to 50\% flowering (days), plant height $(\mathrm{cm})$, total tiller/ $\mathrm{m}^{-2}$ under $\mathrm{NO}_{3}{ }^{-}$treatment recorded as 125,505 , 23, 76.8, 92 and 226 respectively. In $\mathrm{N}^{0}$ treatment, mean phenotypic performance for grain yield $\left(\mathrm{g} / \mathrm{m}^{2}\right)$, biological yield $\left(\mathrm{g} / \mathrm{m}^{2}\right)$, harvest index (\%), Days to $50 \%$ flowering (days), plant height $(\mathrm{cm})$, total tiller/ $\mathrm{m}^{-2}$ was observed as $88,375,22,78,82$ and 226 respectively. Under terminal stage drought, mean phenotypic performance values recorded in $\mathrm{NH}_{4}^{+}$treatment for grain yield $\left(\mathrm{g} / \mathrm{m}^{2}\right)$, biological yield $\left(\mathrm{g} / \mathrm{m}^{2}\right)$, harvest index (\%), Days to $50 \%$ flowering (days), plant height $(\mathrm{cm})$, effective tiller/plant, total tiller/ plant was reported as $130,528,24,80,101,9$ and 8 respectively. Mean phenotypic performance values in $\mathrm{NO}_{3}{ }^{-}$treatment for grain yield $\left(\mathrm{g} / \mathrm{m}^{2}\right)$, biological yield $\left(\mathrm{g} / \mathrm{m}^{2}\right)$, harvest index (\%), Days to $50 \%$ flowering (days), plant height $(\mathrm{cm})$, effective tiller/plant, total tiller/ plant was observed as 90, 365, 24, $81,90,8.6$ and 7.8 respectively. Mean phenotypic performance values recorded in $\mathrm{N}^{0}$ treatment for grain yield $\left(\mathrm{g} / \mathrm{m}^{2}\right)$, biological yield $\left(\mathrm{g} / \mathrm{m}^{2}\right)$, harvest index (\%), Days to $50 \%$ flowering (days), plant height $(\mathrm{cm})$, effective tiller/plant, total tiller/ plant was 89, 327, $27.9,81,89,7.8$ and 7.2 , respectively. These findings collaborates with the study of Singh et al. (2014) who evaluated the genotypic variation among 5 rice genotypes at 4 nitrogen availability in relations to grain yield, biological yield, panicle weight, primary and secondary branch, and recorded significant correlation between nitrogen doses and above 
discussed traits. Also, Rahman et al., (2004) on their paper, "response of photosensitive rice to nitrogen levels in boro season" reported variation in plant height for rice variety at variable $\mathrm{N}$ doses.

\section{NUE and NUE related traits}

\section{Analysis of variance and mean performance of genotypes}

The selected 32 RIL lines along with parents during wet season, 2015 was subjected to three way analysis of variance for each character in order to ascertain existence of genotype $\mathrm{x}$ environment $\mathrm{x}$ nitrogen interaction. Analysis of variance revealed that genotypic effects and genotype $\mathrm{x}$ nitrogen interaction effects were significantly different for investigated $\mathrm{N}$ use efficiency and its component traits $(\mathrm{p}<0.05, \mathrm{p}<0.01)$. In the current study, wide ranges of mean values were recorded for chlorophyll parameters, grain nitrogen content, grain protein content, straw nitrogen content, grain $\mathrm{N}$ yield, straw $\mathrm{N}$ yield, biomass $\mathrm{N}$ yield, $\mathrm{N}$ harvest index, $\mathrm{N}$ uptake efficiency, $\mathrm{N}$-utilization efficiency and $\mathrm{N}$-use efficiency. $\mathrm{N}$-concentration traits and $\mathrm{N}$-use efficiency traits varied significantly across different $\mathrm{N}$ and water regimes. The results of detailed statistics with ANOVA and its variance component and mean values estranged with standard error of mean are presented in tables 3 and 4. The radar graph depicted shows the difference in phenotypic performance of two parents i.e. Danteshwari and Dagad deshi for yield and NUE related traits under $\mathrm{NH}_{4}{ }^{+}$and $\mathrm{NO}_{3}{ }^{-}$treatment over $\mathrm{N}^{0}$ treatment across two environments.

Mean phenotypic performance of two parents showed significant differences for evaluated NUE traits. The coefficient of variation (CV) ranged from $6 \%$ to $34 \%$ for investigated traits. Under irrigated condition, in $\mathrm{NH}_{4}^{+}$ treatment, grain nitrogen content ranged from
1.02-1.4 (\%) with an average value of 1.23 $(\%)$, mean phenotypic value for straw nitrogen content ranged from 0.3-0.6 (\%) with an average value of $0.5(\%)$. Grain nitrogen yield values ranged from 1.49 to $6.9\left(\mathrm{~g} / \mathrm{m}^{2}\right)$ with a mean value of $3.5 \mathrm{~g} / \mathrm{m}^{2}$. The mean phenotypic values for straw nitrogen yield ranged from 1.4-4.8 $\left(\mathrm{g} / \mathrm{m}^{2}\right)$ with an average value of $2.7\left(\mathrm{~g} / \mathrm{m}^{2}\right)$. Biological nitrogen yield ranged from $2.9-11.2\left(\mathrm{~g} / \mathrm{m}^{2}\right)$ with a mean value of $6.3 \mathrm{~g} / \mathrm{m}^{2}$. Nitrogen harvest index ranged from 25.8-69.1 (\%) depicting mean of $55.5(\%)$. N-uptake efficiency values ranged from $0.1-0.3\left(\mathrm{gg}^{-1} \mathrm{~N}\right)$ with average value of $0.20 \quad\left(\mathrm{gg}^{-1} \quad \mathrm{~N}\right)$. N-utilization efficiency recorded mean values of $45.2\left(\mathrm{gg}^{-1} \mathrm{~N}\right)$ and range of $18.9-59\left(\mathrm{gg}^{-1} \mathrm{~N}\right)$. N-use efficiency ranged from 3.8-17.1 $\left(\mathrm{gg}^{-1} \mathrm{~N}\right)$ with mean value of $9.8\left(\mathrm{gg}^{-1} \mathrm{~N}\right)$. In $\mathrm{NO}_{3}^{-}$treatment, mean phenotypic value of grain nitrogen content was $1.14 \%$ and values ranged from 0.98-1.32 (\%). Straw nitrogen content ranged from $0.35-0.62$ $(\%)$ with a mean value of $0.47(\%)$, mean phenotypic value of grain $\mathrm{N}$ yield ranged from $1.6-4.8\left(\mathrm{~g} / \mathrm{m}^{2}\right)$ with an average value of 2.6 $\left(\mathrm{g} / \mathrm{m}^{2}\right)$. Straw $\mathrm{N}$ yield ranged from 1.1-5.3 $\left(\mathrm{g} / \mathrm{m}^{2}\right)$ with mean value of $2.1\left(\mathrm{~g} / \mathrm{m}^{2}\right)$. Biological $\mathrm{N}$ yield ranged from $2.8-10.1\left(\mathrm{~g} / \mathrm{m}^{2}\right)$ with an average value of $4.7\left(\mathrm{~g} / \mathrm{m}^{2}\right)$. The range of variation for nitrogen harvest index was from 45.8 to $66.3(\%)$ with mean value of 56.1 $(\%)$. The range of variation for $\mathrm{N}$-uptake efficiency was $0.1-0.3\left(\mathrm{gg}^{-1} \mathrm{~N}\right)$ with average value of $0.15\left(\mathrm{gg}^{-1} \mathrm{~N}\right)$. The range of variation for N-utilization efficiency is from 34.6 to 60.6 $\left(\mathrm{gg}^{-1} \mathrm{~N}\right)$ with mean value of 48.9. Mean phenotypic value for $\mathrm{N}$-use efficiency is 7.77 $\left(\mathrm{gg}^{-1} \mathrm{~N}\right)$ with range from 4.5-12.7 $\left(\mathrm{gg}^{-1} \mathrm{~N}\right)$. In $\mathrm{N}^{0}$ treatment, the range of variation for grain nitrogen content ranged from 0.7-1.3(\%) with mean phenotypic value of $1.11(\%)$. The range of variation for straw nitrogen content is from $0.27-0.65(\%)$ with mean value of $0.45(\%)$. Phenotypic performance for grain nitrogen yield ranged from $0.91-4.1\left(\mathrm{~g} / \mathrm{m}^{2}\right)$ with mean value of $2.42\left(\mathrm{~g} / \mathrm{m}^{2}\right)$. Straw nitrogen yield 
ranged from $0.5-3.01\left(\mathrm{~g} / \mathrm{m}^{2}\right)$ with average value of $1.7 \mathrm{~g} / \mathrm{m}^{2}$. The range of variation for biomass $\mathrm{N}$ yield was from 2.0 to $6.3 \mathrm{~g} / \mathrm{m}^{2}$, for nitrogen harvest index was from 36.4-74.7 $\mathrm{g} / \mathrm{m}^{2}$, for N-uptake efficiency was from $0.1-0.3$ $\mathrm{gg}^{-1} \mathrm{~N}$, for N-utilization efficiency from 28.5 $66.6 \mathrm{gg}^{-1} \mathrm{~N}$, for $\mathrm{N}$-use efficiency ranged from 4.0-17.1 $\mathrm{gg}^{-1} \mathrm{~N}$ and average value for these traits are $4.2 \mathrm{~g} / \mathrm{m}^{2}, 56.7 \%, 0.18 \mathrm{gg}^{-1} \mathrm{~N}, 51.6 \mathrm{gg}$ ${ }^{1} \mathrm{~N}, 9.81 \mathrm{gg}^{-1} \mathrm{~N}$.

Under rainfed condition, in $\mathrm{NH}_{4}{ }^{+}$treatment mean phenotypic values recorded for grain $\mathrm{N}$ content (\%), straw $\mathrm{N}$ content $(\%)$, grain $\mathrm{N}$ yield $\left(\mathrm{g} / \mathrm{m}^{2}\right)$, straw $\mathrm{N}$ yield $\left(\mathrm{g} / \mathrm{m}^{2}\right)$, Biological $\mathrm{N}$ yield $\left(\mathrm{g} / \mathrm{m}^{2}\right)$, Nitrogen harvest index $(\%)$, $\mathrm{N}$-uptake efficiency $\left(\mathrm{gg}^{-1} \mathrm{~N}\right), \quad \mathrm{N}$-utilization efficiency $\left(\mathrm{gg}^{-1} \mathrm{~N}\right)$, N-use efficiency $\left(\mathrm{gg}^{-1} \mathrm{~N}\right)$ are $1.5,8.9,0.9,2.02,4.05,6.07,32.8,0.22$, 21.8 and 5.02. In $\mathrm{NO}_{3}^{-}$treatment mean phenotypic values recorded for grain $\mathrm{N}$ content (\%), straw $\mathrm{N}$ content $(\%)$, grain $\mathrm{N}$ yield $\left(\mathrm{g} / \mathrm{m}^{2}\right)$, straw $\mathrm{N}$ yield $\left(\mathrm{g} / \mathrm{m}^{2}\right)$, Biological $\mathrm{N}$ yield $\left(\mathrm{g} / \mathrm{m}^{2}\right)$, Nitrogen harvest index $(\%)$, $\mathrm{N}$-uptake efficiency $\left(\mathrm{gg}^{-1} \mathrm{~N}\right), \quad \mathrm{N}$-utilization efficiency $\left(\mathrm{gg}^{-1} \mathrm{~N}\right)$, N-use efficiency $\left(\mathrm{gg}^{-1} \mathrm{~N}\right)$ are $1.37,8.21,0.81,1.7,3.05,4.76,34.7$, $0.17,25.1$ and 4.7 .

Table.1 Physio-chemical properties of the soil from the experimental site

\begin{tabular}{ccc} 
& \multicolumn{2}{c}{ Values } \\
Physio-chemical properties & I & RF \\
\hline$>\mathrm{pH}(1: 2.5)$ & 7.3 & 7.1 \\
$>\mathrm{EC}\left(\mathrm{dsm}^{-1}\right)$ & 0.21 & 0.16 \\
$>\mathrm{Organic}$ carbon $(\%)$ & 0.59 & 0.34 \\
$>\mathrm{N}(\mathrm{kg} / \mathrm{ha})$ & 210.53 & 184.9 \\
$>\mathrm{P}(\mathrm{kg} / \mathrm{ha})$ & 18.73 & 14.23 \\
$>\mathrm{K}(\mathrm{kg} / \mathrm{ha})$ & 516.57 & 342.15 \\
$>$ Ammonical N $(\mathrm{mg} / \mathrm{kg})$ & 9.01 & 8.26 \\
$>$ Nitrate N $(\mathrm{mg} / \mathrm{kg})$ & 9.66 & 8.55 \\
\hline
\end{tabular}

Table.2 Pearson's correlation coefficients between important grain yield and NUE component traits under differential $\mathrm{N}$ regimes under irrigated and rainfed condition during wet season, 2015

\begin{tabular}{|c|c|c|c|c|c|c|}
\hline \multirow{3}{*}{ Traits } & \multicolumn{3}{|c|}{ IRRIGATED } & \multicolumn{3}{|c|}{ RAINFED } \\
\hline & $\mathrm{NH}_{4}{ }^{+}$ & $\mathrm{NO}_{3}^{-}$ & $\mathbf{N}^{0}$ & $\mathrm{NH}_{4}^{+}$ & $\mathrm{NO}_{3}^{-}$ & $\mathbf{N}^{0}$ \\
\hline & GY & GY & GY & GY & GY & GY \\
\hline GNY & $0.95 * *$ & $0.92 * *$ & $0.95 * *$ & $0.94 * *$ & $0.95 * *$ & $0.98 * *$ \\
\hline NUpE & $0.82 * *$ & $0.80 * *$ & $0.81 * *$ & $0.75^{* *}$ & $0.56 * *$ & $0.64 * *$ \\
\hline NUtE & $0.57 * *$ & $0.57 * *$ & $0.66 * *$ & $0.78 * *$ & $0.81 * *$ & $0.81 * *$ \\
\hline NUE & $0.98 * *$ & $0.97 * *$ & $0.99 * *$ & $0.89 * *$ & $0.99 * *$ & $0.96 * *$ \\
\hline $\mathrm{NHI}$ & $0.57 * *$ & $0.36 * * *$ & $0.53 * *$ & $0.75 * *$ & $0.85 * *$ & $0.82 * *$ \\
\hline
\end{tabular}

$* *$ Significance at $5 \%$ where, $\mathrm{GY}=$ grain yield, $\mathrm{GNY}=$ grain $\mathrm{N}$ yield, $\mathrm{NUpE}=\mathrm{N}$ uptake efficiency, $\mathrm{NUtE}=\mathrm{N}$ utilization efficiency, $\mathrm{NUE}=\mathrm{N}$ use efficiency 
Table.3 Mean phenotypic performance, range, standard deviation (SD), Coefficient of variance (CV \%) of investigated yield and yield related traits of 122 and 32 selected RILs and their parents under differentia N regimes and environments during wet season 2015

\begin{tabular}{|c|c|c|c|c|c|c|c|c|c|c|c|}
\hline \multirow{4}{*}{ Traits } & \multirow{4}{*}{$\mathrm{N}$} & & & & & & \multicolumn{5}{|c|}{ Wet season 2015} \\
\hline & & \multicolumn{5}{|c|}{ IRRIGATED (I) } & \multirow{3}{*}{$\mathrm{D}$} & \multicolumn{3}{|c|}{ RAINFED (R) } & \multirow[b]{3}{*}{ CV\% } \\
\hline & & \multirow{2}{*}{$\mathrm{D}$} & \multirow{2}{*}{ DD } & \multicolumn{2}{|c|}{ RILs } & \multirow[b]{2}{*}{$\mathrm{CV} \%$} & & DD & & & \\
\hline & & & & Mean \pm SEm & Range & & & DD & Mean \pm SEm & Range & \\
\hline \multirow[t]{3}{*}{ GY } & $\mathrm{NH}_{4}^{+}$ & 169 & 256 & $284 \pm 17.1$ & $117.3-522.5$ & 34.1 & 80.5 & 221 & $136 \pm 8.8$ & $48-248$ & 36 \\
\hline & $\mathrm{NO}_{3}^{-}$ & 253 & 232 & $233.3 \pm 8.9$ & $135-381.5$ & 22 & 71.6 & 239 & $125 \pm 10.4$ & $29-261$ & 46 \\
\hline & $\mathrm{N}^{0}$ & 267 & 201 & $221.3 \pm 12.9$ & $90.6-383.6$ & 33 & 64.4 & 162.7 & $88 \pm 6.0$ & $20-162$ & 39 \\
\hline \multirow[t]{3}{*}{ BY } & $\mathrm{NH}_{4}^{+}$ & 429 & 647.1 & $849.9 \pm 41.0$ & $372.5-1238.9$ & 27.3 & 317 & 1042 & $588 \pm 27.5$ & $317-1042$ & 26 \\
\hline & $\mathrm{NO}_{3}^{-}$ & 631.6 & 614.9 & $674 \pm 31.3$ & $427.1-1388.1$ & 26 & 362 & 724 & $505 \pm 23$ & $247-740$ & 26 \\
\hline & $\mathrm{N}^{0}$ & 654 & 521 & $613 \pm 26.1$ & $310.4-921.5$ & 24 & 256 & 518 & $375 \pm 15.7$ & $151-546$ & 23 \\
\hline \multirow[t]{3}{*}{$\mathrm{HI}$} & $\mathrm{NH}_{4}^{+}$ & 37 & 39 & $34 \pm 1.2$ & $11.4-46.7$ & 19.7 & 25 & 21 & $23 \pm 0.9$ & $9.4-36.3$ & 23 \\
\hline & $\mathrm{NO}_{3}^{-}$ & 39 & 37 & $35.2 \pm 0.8$ & $25.2-43.3$ & 13 & 19 & 32 & $23 \pm 1.0$ & $11.9-35$ & 23 \\
\hline & $\mathrm{N}^{0}$ & 41 & 38 & $35.5 \pm 1.2$ & $19.2-46.3$ & 19 & 25 & 30 & $22 \pm 1.0$ & $13-33$ & 25 \\
\hline \multirow[t]{3}{*}{$\mathrm{TT} / \mathrm{m}^{2}$} & $\mathrm{NH}_{4}^{+}$ & & & & & & 429 & 357 & $440 \pm 13.4$ & $295-617$ & 17 \\
\hline & $\mathrm{NO}_{3}^{-}$ & & & & & & 362 & 724 & $394 \pm 7.7$ & 139-301 & 19 \\
\hline & $\mathrm{N}^{0}$ & & & & & & 488 & 323 & $226 \pm 13$ & $275-569$ & 20 \\
\hline \multirow[t]{3}{*}{ TT/P } & $\mathrm{NH}_{4}^{+}$ & 9 & 5.3 & $8.1 \pm 0.28$ & $5.0-12.0$ & 19 & & & & & \\
\hline & $\mathrm{NO}_{3}^{-}$ & 7.5 & 3.6 & $6.76 \pm 0.2$ & $3.6-9.5$ & 19 & & & & & \\
\hline & $\mathrm{N}^{0}$ & 6.7 & 3.4 & $6.5 \pm 0.2$ & $3.4-9.4$ & 19 & & & & & \\
\hline \multirow[t]{3}{*}{$\mathrm{ET} / \mathrm{P}$} & $\mathrm{NH}_{4}^{+}$ & 8.5 & 5 & $6.9 \pm 0.3$ & $3-9.9$ & 25 & & & & & \\
\hline & $\mathrm{NO}_{3}^{-}$ & 7.3 & 3.6 & $6.2 \pm 0.2$ & $3.6-9.3$ & 19 & & & & & \\
\hline & $\mathrm{N}^{0}$ & 6.1 & 3.4 & $6.2 \pm 0.2$ & $3.4-8.5$ & 19 & & & & & \\
\hline \multirow[t]{3}{*}{ SB } & $\mathrm{NH}_{4}^{+}$ & 2.2 & 4.2 & $3.85 \pm 0.28$ & $2.0-9.3$ & 33 & 5.8 & 6.5 & $5.09 \pm 0.23$ & 2.4-7.9 & 26 \\
\hline & $\mathrm{NO}_{3}^{-}$ & 1.3 & 3.5 & $2.9 \pm 0.10$ & $1.3-3.5$ & 28 & 2.9 & 5 & $3.4 \pm 0.1$ & $2.0-6.1$ & 31 \\
\hline & $\mathrm{N}^{0}$ & 2.38 & 2.53 & $3.1 \pm 0.1$ & $1.9-4.8$ & 24 & 1.5 & 2.2 & $2.2 \pm 0.1$ & $1.2-3.3$ & 24 \\
\hline \multirow[t]{3}{*}{ DTF } & $\mathrm{NH}_{4}^{+}$ & 80 & 70 & $76.4 \pm 1.4$ & $66-102.5$ & 11 & 79 & 67 & $76 \pm 1.6$ & $62.5-102.5$ & 17 \\
\hline & $\mathrm{NO}_{3}^{-}$ & 79 & 70 & $78.4 \pm 1.5$ & $67.5-104$ & 10 & 79 & 67 & $76.8 \pm 1.6$ & 65-104 & 11 \\
\hline & $\mathrm{N}^{0}$ & 76 & 68 & $76.4 \pm 1.5$ & $66.5-103$ & 11 & 83 & 68 & $78 \pm 1.4$ & $68-100$ & 11 \\
\hline \multirow[t]{3}{*}{$\mathrm{PH}$} & $\mathrm{NH}_{4}^{+}$ & 79 & 128 & $106 \pm 3.7$ & $74-147$ & 20 & 81 & 130 & $99 \pm 3.2$ & $73.6-135$ & 12 \\
\hline & $\mathrm{NO}_{3}^{-}$ & 75 & 116 & $97.7 \pm 3.3$ & $64.6-132$ & 19 & 77 & 122 & $92 \pm 3.1$ & $64-125$ & 19 \\
\hline & $\mathrm{N}^{0}$ & 81 & 117 & $96.1 \pm 2.9$ & $64.4-132$ & 17 & 72 & 103 & $82 \pm 2.6$ & $63-116$ & 18 \\
\hline \multirow[t]{3}{*}{ PL } & $\mathrm{NH}_{4}^{+}$ & 22 & 23 & $23.4 \pm 0.4$ & $20.3-32.6$ & 10 & 20 & 25.5 & $22 \pm 0.4$ & $18.7-27.4$ & 10 \\
\hline & $\mathrm{NO}_{3}^{-}$ & 22 & 24 & $22.5 \pm 0.3$ & $19.1-30.3$ & 9 & 18 & 24 & $21 \pm 0.4$ & $18-26.4$ & 10 \\
\hline & $\mathrm{N}^{0}$ & 21 & 22 & $21.6 \pm 0.3$ & $18.3-25.8$ & 7 & 17 & 20 & $19 \pm 0.3$ & $14-34$ & 9 \\
\hline FLL & $\mathrm{NH}_{4}^{+}$ & 26 & 33 & $30.5 \pm 0.93$ & $21.1-44.2$ & 17 & 24 & 37 & $29 \pm 1.00$ & $19-45$ & 19 \\
\hline
\end{tabular}


Table.4 Mean phenotypic performance, range, standard deviation (SD), Coefficient of variance (CV \%) of investigated chlorophyll parameters, NUE and its component traits of 32 selected RILs and their parents under differential N regimes and environments during wet season, 2015

\begin{tabular}{|c|c|c|c|c|c|c|c|c|c|c|c|c|c|c|c|c|c|c|}
\hline \multirow{4}{*}{ Traits } & \multirow{4}{*}{$\mathbf{N}$} & \multirow{2}{*}{\multicolumn{7}{|c|}{ Source of variation }} & \multicolumn{5}{|c|}{ IRRIGATED (I) } & \multicolumn{5}{|c|}{ RAINFED (R) } \\
\hline & & & & & & & & & \multirow[b]{2}{*}{$\mathrm{D}$} & \multirow[b]{2}{*}{ DD } & \multicolumn{2}{|c|}{ RILs } & \multirow[b]{2}{*}{$\begin{array}{l}\mathrm{C} \\
\mathrm{V} \\
\%\end{array}$} & \multirow[t]{2}{*}{$\mathrm{D}$} & \multirow{2}{*}{$\begin{array}{l}\mathrm{D} \\
\mathrm{D}\end{array}$} & \multicolumn{2}{|l|}{ RILs } & \multirow[b]{2}{*}{$\begin{array}{l}\mathrm{C} \\
\mathrm{V} \\
\%\end{array}$} \\
\hline & & $\mathbf{G}$ & $\mathbf{N}$ & $\mathbf{E}$ & E X G & N X G & EX N & $\underset{G}{\mathbf{E} X \mathbf{N} X}$ & & & $\begin{array}{l}\text { Mean } \pm \text { SE } \\
m\end{array}$ & Range & & & & $\begin{array}{l}\text { Mean } \pm \text { SE } \\
m\end{array}$ & Range & \\
\hline & & $\begin{array}{l}\text { TMSS, } \\
\text { DF=31 }\end{array}$ & $\begin{array}{c}\text { TMSS, } \\
\text { DF }=2\end{array}$ & $\begin{array}{c}\text { TMSS, } \\
\text { DF=1 }\end{array}$ & $\begin{array}{l}\text { TMSS, } \\
\text { DF=31 }\end{array}$ & $\begin{array}{l}\text { TMSS, } \\
\text { DF=62 }\end{array}$ & $\begin{array}{c}\text { TMSS, } \\
\text { DF }=2\end{array}$ & $\begin{array}{l}\text { TMSS, } \\
\text { DF }=62\end{array}$ & & & & & & & & & & \\
\hline \multirow[t]{3}{*}{$\begin{array}{l}\text { SPA } \\
\mathrm{D} \text { till }\end{array}$} & $\mathrm{NH}_{4}^{+}$ & & & & & & & & 35 & 32 & $32.6 \pm 0.3$ & $29.7-37$ & 6 & $\begin{array}{c}35.0 \\
7\end{array}$ & 31.9 & $32.7 \pm 0.4$ & $\begin{array}{l}29.7- \\
36.5\end{array}$ & 6 \\
\hline & $\mathrm{NO}_{3}^{-}$ & $\begin{array}{c}49.24 \\
* * *\end{array}$ & $\begin{array}{c}186.5 \\
* * *\end{array}$ & NS & NS & $5.3 *$ & NS & NS & 31 & 32 & $31.5 \pm 0.4$ & $26.3-38$ & 7 & 33.7 & 30.5 & $31.5 \pm 0.4$ & $\begin{array}{c}26.3- \\
38.7\end{array}$ & 7 \\
\hline & $\mathrm{N}^{0}$ & & & & & & & & 31 & 31 & $30.3 \pm 0.4$ & $26.3-35$ & 7 & 32 & 30.1 & $30.4 \pm 0.4$ & $\begin{array}{l}26.4- \\
34.9\end{array}$ & 7 \\
\hline \multirow[t]{3}{*}{$\begin{array}{l}\text { SPA } \\
\text { D fl }\end{array}$} & $\mathrm{NH}_{4}^{+}$ & & & & & & & & 35 & 34 & $36.1 \pm 0.4$ & $30.5-40.5$ & 6 & 38.1 & 40.2 & $37.7 \pm 0.6$ & $28-43.1$ & 8 \\
\hline & $\mathrm{NO}_{3}^{-}$ & $\begin{array}{l}50.2 \\
* * *\end{array}$ & $\begin{array}{c}190.1 \\
* * *\end{array}$ & NS & NS & $6.6 *$ & NS & NS & 37 & 35 & $35.8 \pm 1.3$ & $\begin{array}{c}28.6- \\
42.3\end{array}$ & 6 & 34.5 & 37.4 & $35.5 \pm 0.05$ & $\begin{array}{c}29.6- \\
41.4\end{array}$ & 8 \\
\hline & $\mathrm{N}^{0}$ & & & & & & & & 37 & 29 & $32.1 \pm 0.5$ & $\begin{array}{c}24.3- \\
37.2\end{array}$ & 7 & 31 & 28 & $28.4 \pm 0.5$ & $\begin{array}{l}22.8- \\
33.2\end{array}$ & 10 \\
\hline \multirow[t]{3}{*}{ GNC } & $\mathrm{NH}_{4}^{+}$ & & & & & & & & 1.4 & 1.2 & $1.23 \pm 0.02$ & $1.02-1.4$ & 10 & 1.7 & 1.6 & $1.5 \pm 0.03$ & $1.1-1.8$ & 12 \\
\hline & $\mathrm{NO}_{3}^{-}$ & $\begin{array}{l}0.05 \\
* * *\end{array}$ & $\begin{array}{l}1.69 \\
* * *\end{array}$ & $\begin{array}{c}3.1 \\
* * *\end{array}$ & $\begin{array}{c}0.047 \\
* * *\end{array}$ & $\begin{array}{l}0.03 \\
* * *\end{array}$ & $\begin{array}{l}0.42 \\
* * *\end{array}$ & $0.29 *$ & 1.1 & 1.2 & $1.14 \pm 0.01$ & $\begin{array}{c}0.98- \\
1.32\end{array}$ & 8 & 1.27 & 1.17 & $1.37 \pm 0.02$ & $1.1-1.7$ & 11 \\
\hline & $\mathrm{N}^{0}$ & & & & & & & & 1.0 & 1.2 & $1.11 \pm 0.01$ & $0.7-1.3$ & 7 & 1.29 & 1.16 & $1.2 \pm 0.01$ & $1.0-1.4$ & 8 \\
\hline \multirow[t]{3}{*}{ GPC } & $\mathrm{NH}_{4}^{+}$ & & & & & & & & 8.2 & 6.9 & $7.3 \pm 0.12$ & $6.1-8.7$ & 10 & 10.2 & 9.6 & $8.9 \pm 0.2$ & $6.9-11.1$ & 13 \\
\hline & $\mathrm{NO}_{3}^{-}$ & $* * *$ & $* * *$ & $* * *$ & $* * *$ & $* * *$ & $* * *$ & $* * *$ & 6.5 & 7.4 & $6.8 \pm 0.1$ & $5.8-8.1$ & 8 & 7.54 & 6.96 & $8.21 \pm 0.17$ & $6.8-10.4$ & 12 \\
\hline & $\mathrm{N}^{0}$ & & & & & & & & 5.8 & 7.0 & $6.6 \pm 0.11$ & $4.6-7.8$ & 8 & 7.66 & 6.91 & $6.9 \pm 0.09$ & $6.1-8.3$ & 8 \\
\hline \multirow[t]{3}{*}{ SNC } & $\mathrm{NH}_{4}^{+}$ & & & & & & & & 0.6 & 0.5 & $0.5 \pm 0.01$ & $0.3-0.6$ & 18 & 1.1 & 0.7 & $0.9 \pm 0.03$ & $0.6-1.6$ & 21 \\
\hline & $\mathrm{NO}_{3}^{-}$ & $\begin{array}{l}0.09 \\
* * *\end{array}$ & $\begin{array}{l}0.89 \\
* * *\end{array}$ & $\begin{array}{l}9.32 \\
* * *\end{array}$ & $\begin{array}{l}0.04 \\
* * *\end{array}$ & $\begin{array}{l}0.02 \\
* * *\end{array}$ & $\begin{array}{l}0.47 \\
* * *\end{array}$ & $\begin{array}{l}0.01 \\
* * *\end{array}$ & 0.5 & 0.5 & $0.47 \pm 0.01$ & $\begin{array}{c}0.35- \\
0.62\end{array}$ & 12 & 0.97 & 0.55 & $0.81 \pm 0.02$ & $0.54-1.18$ & 19 \\
\hline & $\mathrm{N}^{0}$ & & & & & & & & 0.5 & 0.5 & $0.45 \pm 0.01$ & $\begin{array}{c}0.27- \\
0.65\end{array}$ & 14 & 0.76 & 0.51 & $0.63 \pm 0.1$ & $0.4-1.04$ & 21 \\
\hline \multirow[t]{3}{*}{ GNY } & $\mathrm{NH}_{4}^{+}$ & 3.02 & 35.10 & 158.1 & 2.1 & 0.73 & 2.73 & & 2.4 & 3.0 & $3.5 \pm 0.2$ & $1.4-6.9$ & 35 & 1.4 & 3.6 & $2.02 \pm 0.13$ & $0.8-3.5$ & 37 \\
\hline & $\mathrm{NO}_{3}^{-}$ & $* * *$ & $* * *$ & $* * *$ & $* * *$ & $* * *$ & $* * *$ & $* * *$ & 2.8 & 2.9 & $2.6 \pm 0.11$ & $1.6-4.8$ & 23 & 0.91 & 2.78 & $1.7 \pm 0.1$ & $0.5-3.2$ & 44 \\
\hline & $\mathrm{N}^{+}$ & & & & & & & & 2.6 & 2.4 & $2.42 \pm 0.13$ & $0.9-4.1$ & 22 & 0.83 & 1.90 & $1.02 \pm 0.1$ & $0.2-2.04$ & 21 \\
\hline Siv & $\mathrm{NH}_{4}$ & 1.66 & 84.4 & 53.89 & 1.66 & 0.98 & 13.8 & 0.77 & 1.5 & 2.1 & $2.7 \pm 0.16$ & $1.4-4.8$ & 33 & 2.6 & 6.1 & $4.05 \pm 0.16$ & $2.5-6.6$ & 23 \\
\hline
\end{tabular}


Int.J.Curr.Microbiol.App.Sci (2017) 6(6): 1701-1713

\begin{tabular}{|c|c|c|c|c|c|c|c|c|c|c|c|c|c|c|c|c|c|c|}
\hline & $\mathrm{NO}_{3}^{-}$ & $* * *$ & $* * *$ & $* * *$ & $* * *$ & $* * *$ & $* * *$ & $* * *$ & 2.0 & 1.9 & $2.1 \pm 0.2$ & $1.1-5.3$ & 35 & 2.84 & 2.66 & $3.05 \pm 0.12$ & $1.9-5.4$ & 21 \\
\hline \multirow{4}{*}{$\mathrm{BNY}$} & $\mathrm{N}^{0}$ & & & & & & & & 1.9 & 1.5 & $1.7 \pm 0.1$ & $0.5-3.01$ & 32 & 1.45 & 1.83 & $1.78 \pm 0.09$ & $0.8-3.1$ & 41 \\
\hline & $\mathrm{NH}_{4}^{+}$ & & & 2737 & & & 1773 & & 3.9 & 5.1 & $6.3 \pm 0.3$ & $2.9-11.2$ & 28 & 4.0 & 9.6 & $6.07 \pm 0.2$ & $3.9-9.6$ & 23 \\
\hline & $\mathrm{NO}_{3}^{-}$ & $* * *$ & $* * *$ & $* * *$ & $* * *$ & $* * *$ & $* * *$ & $* * *$ & 4.7 & 4.8 & $4.7 \pm 0.1$ & $2.8-10.1$ & 26 & 3.75 & 5.44 & $4.76 \pm 0.21$ & $2.6-7.2$ & 25 \\
\hline & & & & & & & & & 4.5 & 3.9 & $4.2 \pm 0.2$ & $2.0-6.3$ & 24 & 2.28 & 3.73 & $2.82 \pm 0.12$ & $1.1-4.3$ & 27 \\
\hline \multirow[t]{3}{*}{ NHI } & $\mathrm{NH}_{4}{ }^{+}$ & & & & & & & & 58.8 & 58.4 & $55.5 \pm 1.6$ & $\begin{array}{l}25.8- \\
69.1\end{array}$ & 17 & 35.2 & 36.9 & $32.8 \pm 1.2$ & $17.1-45$ & 21 \\
\hline & $\mathrm{NO}_{3}^{-}$ & $\begin{array}{c}381.6 \\
* * *\end{array}$ & $\begin{array}{c}121.1 \\
*\end{array}$ & $\begin{array}{c}45,655 \\
* * *\end{array}$ & $\begin{array}{c}183.1 \\
* * *\end{array}$ & $\begin{array}{l}84.5 \\
* * *\end{array}$ & $\begin{array}{l}20.5 \\
* * *\end{array}$ & $\begin{array}{c}84.17 \\
* * *\end{array}$ & 57.9 & 60.6 & $56.1 \pm 1.01$ & $\begin{array}{c}45.8- \\
66.3\end{array}$ & 10 & 24.31 & 50.51 & $34.7 \pm 1.7$ & $16.5-50.5$ & 27 \\
\hline & $\mathrm{N}^{0}$ & & & & & & & & 57.3 & 61.8 & $56.7 \pm 1.6$ & $\begin{array}{c}36.4 \pm 74 \\
7\end{array}$ & 11 & 36.24 & 49.85 & $35.5 \pm 1.7$ & $20-52$ & 24 \\
\hline \multirow[t]{3}{*}{$\begin{array}{c}\text { NUp } \\
\text { E }\end{array}$} & $\mathrm{NH}_{4}^{+}$ & & & & & & & & 0.1 & 0.2 & $0.20 \pm 0.01$ & $0.1-0.3$ & 28 & 0.1 & 0.4 & $0.22 \pm 0.01$ & $0.14-0.36$ & 24 \\
\hline & $\mathrm{NO}_{3}^{-}$ & $\begin{array}{l}0.25 \\
* * *\end{array}$ & $\begin{array}{l}0.17 \\
* * *\end{array}$ & $\begin{array}{l}0.01 \\
* * *\end{array}$ & $\begin{array}{l}0.01 \\
* * *\end{array}$ & $\begin{array}{l}0.003 \\
* * *\end{array}$ & $\begin{array}{l}0.11 \\
* * *\end{array}$ & $\begin{array}{c}0.003 \\
* * *\end{array}$ & 0.2 & 0.2 & $0.15 \pm 0.0$ & $0.1-0.3$ & 26 & 0.14 & 0.21 & $0.17 \pm 0.00$ & $0.10-0.27$ & 25 \\
\hline & $\mathrm{N}^{0}$ & & & & & & & & 0.2 & 0.2 & $0.18 \pm 0.0$ & $0.1-0.3$ & 23 & 0.09 & 0.14 & $0.10 \pm 0.00$ & $0.04-0.16$ & $\begin{array}{l}28 \\
06\end{array}$ \\
\hline \multirow[t]{3}{*}{ NUtE } & $\mathrm{NH}_{4}{ }^{+}$ & & & & & & & & 42.8 & 50.3 & $45.2 \pm 1.4$ & $18.9-59$ & 18 & 20.5 & 22.8 & $21.8 \pm 0.87$ & $9.4-33.1$ & 22 \\
\hline & $\mathrm{NO}_{3}^{-}$ & $\begin{array}{c}343.9 \\
* * *\end{array}$ & $\begin{array}{c}1,753 \\
* * *\end{array}$ & $\begin{array}{c}47,295 \\
* * *\end{array}$ & $\begin{array}{c}166.7 \\
* * *\end{array}$ & $\begin{array}{l}100.0 \\
* * *\end{array}$ & NS & $\begin{array}{c}104.3 \\
* * *\end{array}$ & 53.3 & 48.9 & $49.4 \pm 1.1$ & $\begin{array}{c}34.6- \\
60.6\end{array}$ & 13 & 19.19 & 43.31 & $25.1 \pm 1.4$ & $9.5-43.3$ & 31 \\
\hline & $\mathrm{N}^{0}$ & & & & & & & & 60.3 & 52.6 & $51.6 \pm 1.7$ & $\begin{array}{c}28.5- \\
66.1\end{array}$ & 12 & 28.14 & 42.86 & $30.5 \pm 1.5$ & $18.8-45.6$ & 27 \\
\hline \multirow[t]{2}{*}{ NUE } & $\mathrm{NH}_{4}^{+}$ & 29.51 & 33.4 & 2,003 & 16.5 & 6.5 & 99 & 4.8 & $\begin{array}{l}5.6 \\
8.5\end{array}$ & $\begin{array}{l}8.5 \\
7.8\end{array}$ & $\begin{array}{c}9.3 \pm 0.5 \\
777+0.3\end{array}$ & $\begin{array}{l}3.8-17.1 \\
45-127\end{array}$ & 34 & $\begin{array}{c}3.1 \\
2.71\end{array}$ & $\begin{array}{c}8.4 \\
9.07\end{array}$ & $5.02 \pm 0.31$ & $\begin{array}{l}1.85-9.42 \\
11.09\end{array}$ & 35 \\
\hline & $\mathrm{N}^{0}$ & $* * *$ & $* * *$ & $* * *$ & $* * *$ & & $* * *$ & $* * *$ & $\begin{array}{l}0.5 \\
12.0\end{array}$ & $\begin{array}{l}1.0 \\
9.0\end{array}$ & $9.81 \pm 0.5$ & $4.0-17.1$ & 20 & 2.44 & 6.17 & $3.3 \pm 0.23$ & $0.75-6.16$ & 39 \\
\hline
\end{tabular}


In $\mathrm{N}^{0}$ treatment, mean phenotypic values recorded for grain $\mathrm{N}$ content $(\%)$, straw $\mathrm{N}$ content $(\%)$, grain $\mathrm{N}$ yield $\left(\mathrm{g} / \mathrm{m}^{2}\right)$, straw $\mathrm{N}$ yield $\left(\mathrm{g} / \mathrm{m}^{2}\right)$, Biological $\mathrm{N}$ yield $\left(\mathrm{g} / \mathrm{m}^{2}\right)$, Nitrogen harvest index (\%), N-uptake efficiency $\left(\mathrm{gg}^{-1} \mathrm{~N}\right), \mathrm{N}$-utilization efficiency $\left(\mathrm{gg}^{-1} \mathrm{~N}\right), \mathrm{N}$-use efficiency $\left(\mathrm{gg}^{-1} \mathrm{~N}\right)$ are 1.2 , $6.9,0.63,1.02,1.78,2.82,35.5,0.10,30.5$ and 3.3 , respectively. These results conclude that ammonium form is more readily absorbed as compared to nitrate form. Furthermore, N available from $\mathrm{NH}_{4}{ }^{+}$treatment is more than $\mathrm{NO}_{3}{ }^{-}$treatment and still less under $\mathrm{N}^{0}$ conditions, therefore these kinds of variation was noticed in different parameters of NUE. These findings synchronize with the work of Beatty et al., (2010), who reported that nitrogen efficient genotypes could be able to produce high grain yields under both low and high $\mathrm{N}$ fertility conditions. Similarly, Belete Woldeyesus Sinebo and Gebrehawarya, (2009) dictated the importance of NUE varieties in future breeding program. Martin et al., (2006) studied N-use efficiency of maize genotypes in contrasting environments. Their results revealed that parameters like chlorophyll content, leaf nitrogen and grain yield are sensitive to $\mathrm{N}$ availability and are important contributors to nitrogen use efficiency. Ali (2005) asserted that productivity and resource use efficiency of rice are affected by crop establishment and nitrogen management. Inthapanya et al., (2000); Zhang et al., (2009) reported genetic variation among rice genotypes in NUE and related traits in rice. Lea and Azevado (2006) further stated that it is very important to identify or develop high NUE genotypes in rice for its production under low cost crop management practices and also to protect environment.

\section{Correlation between grain yield and NUE indices}

Improvement for a trait of interest can be achieved by selection through other traits that are more heritable and easy to select. Therefore, it requires understanding of the interrelationship of the other traits among themselves and with traits of interest. In this study, correlation was established between grain yield and some important NUE indices (Tables 2-4). Under irrigated set of environment, Grain yield showed significant and positive association with Grain $\mathrm{N}$ yield, $\mathrm{N}$-uptake efficiency, N-utilization efficiency, $\mathrm{N}$-use efficiency and Nitrogen harvest index in $\mathrm{NH}_{4}{ }^{+}, \mathrm{NO}_{3}{ }^{-}$and $\mathrm{N}^{0}$ treatment. Similarly, under rainfed condition and all sets of treatment, positive correlation existed between GY and NUE indices. The present study revealed that correlations between grain yield and $\mathrm{N}$ use efficiency traits were mostly positive, significant and strong. This strong and positive correlation between grain yield and $\mathrm{N}$ use efficiency traits provides us with the platform of concurrent improvement of these traits. Similarly, Samont et al., (2006) reported significant and positive correlation between grain $\mathrm{N}$ yield and grain yield in rice. Under this study, $\mathrm{N}$ uptake efficiency had stronger correlation with $\mathrm{N}$ use efficiency as compared to the correlation between $\mathrm{N}$ utilization efficiency. Also, Muurinen et al. (2006) on rice genotypes reported that $\mathrm{N}$ uptake efficiency was far more important than $\mathrm{N}$ utilization efficiency in determining $\mathrm{N}$ use efficiency.

\section{Acknowledgements}

The author is thankful to the Department of Biotechnology (DBT) for awarding a research fellowship for current study.

\section{References}

Ali, M., 2005. Productivity and resource-use efficiency of rice as affected by crop establishment and nitrogen management.

Beatty, P. H., Anbessa, Y., Juskiw, P., 
Carroll, R. T., Wang, J. and Good, A. G., 2010. Nitrogen use efficiencies of spring barley grown under varying nitrogen conditions in the field and growth chamber. Annals of Botany 105:1171-1182.

Belete Woldeyesus Sinebo, K. and Gebrehawarya, Y., 2009. Genetic Variability in Nitrogen Use Efficiency for Yield and Yield Related Traits among Barley (Hordeum vulgare L.) Cultivars. Haramaya University.

Briones Jr, A. M., Okabe, S., Umemiya, Y., Ramsing, N.-B., Reichardt, W. and Okuyama, H., 2003. Ammonia-oxidizing bacteria on root biofilms and their possible contribution to $\mathrm{N}$ use efficiency of different rice cultivars. Plant and Soil 250:335-348.

Fageria, N. and Filho, M., 2001. Nitrogen use efficiency in lowland rice genotypes. Communications in Soil Science and Plant Analysis 32:2079-2089.

Gupta, A., Ahmad, M. F. and Bhat, F., 2010. Studies on yield, quality, water and fertilizer use efficiency of capsicum under drip irrigation and fertigation. Indian Journal of Horticulture 67:213218.

Haefele, S., Jabbar, S., Siopongco, J., TirolPadre, A., Amarante, S., Cruz, P. S. and Cosico, W., 2008. Nitrogen use efficiency in selected rice (Oryza sativa L.) genotypes under different water regimes and nitrogen levels. Field Crops Research 107:137-146.

Huang, J., Reneau, R. and Hagedorn, C., 2000. Nitrogen removal in constructed wetlands employed to treat domestic wastewater. Water Research 34:25822588 .

Inthapanya, P., Sihavong, P., Sihathep, V., Chanphengsay, M., Fukai, S. and Basnayake, J., 2000. Genotype differences in nutrient uptake and utilisation for grain yield production of rainfed lowland rice under fertilised and non-fertilised conditions. Field Crops Research 65:57-68.

Kirk, G. and Kronzucker, H., 2000. Nitrogen uptake by rice roots. Carbon and Nitrogen Dynamics in Flooded Soils Eds GJD Kirk and DC Olk:147-162.

Lea, P. J. and Azevedo, R. A., 2006. Nitrogen use efficiency. 1. Uptake of nitrogen from the soil. Annals of Applied Biology 149:243-247.

Li, B.-Z., Merrick, M., Li, S.-M., Li, H.-Y., Zhu, S.-W., Shi, W.-M. and Su, Y.-H., 2009. Molecular basis and regulation of ammonium transporter in rice. Rice Science 16:314-322.

Li, Z., Yu, S., Wu, S., Wang, J. and Pan, Y., 2003. Effects of different nitrogen fertilizers on the microbial biomass and the population of nitrifying-denitrifying bacteria in the rice rhizosphere. Soils 35:490-494.

Martin, A., Lee, J., Kichey, T., Gerentes, D., Zivy, M., Tatout, C., Dubois, F., Balliau, T., Valot, B. and Davanture, M., 2006. Two cytosolic glutamine synthetase isoforms of maize are specifically involved in the control of grain production. The Plant Cell 18:3252-3274.

Muurinen, S., Kleemola, J. and PeltonenSainio, P., 2007. Accumulation and translocation of nitrogen in spring cereal cultivars differing in nitrogen use efficiency. Agronomy Journal 99:441449.

Rahman, M. A., Sarker, M., Amin, M., Jahan, A. and Akhter, M., 2011. Yield response and nitrogen use efficiency of wheat under different doses and split application of nitrogen fertilizer. Bangladesh Journal of Agricultural Research 36:231-240.

Samonte, S. O. P., Wilson, L. T., Medley, J. C., Pinson, S. R., McClung, A. M. and Lales, J. S., 2006. Nitrogen utilization 
efficiency. Agronomy Journal 98:168176.

Sinebo, W., Gretzmacher, R. and Edelbauer, A., 2004. Genotypic variation for nitrogen use efficiency in Ethiopian barley. Field Crops Research 85:43-60.

Singh, H., Verma, A., Ansari, M. W. and Shukla, A., 2014. Physiological response of rice (Oryza sativa L.) genotypes to elevated nitrogen applied under field conditions. Plant signaling and behavior 9:e29015.

Sokat Yiech., 2006. Nitrogen uptake and yield responses of rainfed rice (Oryza sativa L.) varieties to fertilizer $\mathrm{N}$ on fluvisols of Gambella region. An Msc Thesis presented to the School of Graduate Studies of Haramaya University, Ethiopia

Wang, M. Y., Siddiqi, M. Y., Ruth, T. J. and Glass, A. D., 1993. Ammonium uptake by rice roots (I. Fluxes and subcellular distribution of 13NH4+). Plant Physiology 103:1249-1258.

Weifeng, Z. F. W. J. Z., Xinping, C. Z. M. W. C. and Rongfeng, J., 2008. Nutrient use efficiencies of major cereal crops in China and measures for improvement [J]. Acta Pedologica Sinica 5.

Witcombe, J., Hollington, P., Howarth, C., Reader, S. and Steele, K., 2008. Breeding for abiotic stresses for sustainable agriculture. Philosophical Transactions of the Royal Society of London B: Biological Sciences 363:703-716.

Zhang, Y.-L., Jian-Bo, F., Dong-Sheng, W. and Qi-Rong, S., 2009. Genotypic differences in grain yield and physiological nitrogen use efficiency among rice cultivars. Pedosphere 19:681-691.

\section{How to cite this article:}

Mayur R. Wallalwar, Rashmi Upadhyay, Jyoti Singh, Datta P. Kakade, Shubha Banerjee and Satish B. Verulkar. 2017. Morpho-physiological and Biochemical Characterization of Rice (Oryza sativa L.) Genotypes under Ammonical and Nitrate form of Nitrogen. Int.J.Curr.Microbiol.App.Sci. 6(5): 1701-1713. doi: https://doi.org/10.20546/ijcmas.2017.606.198 